\title{
Pricing Efficiency and Price Discovery of International Crude Oil Futures Prices on China's Crude Oil Spot Prices
}

\author{
Haixia $\mathrm{Wu}^{1, \mathrm{a}}$, Yan $\mathrm{Ge}^{2, \mathrm{~b}}$ \\ ${ }^{1}$ International Business School, Shaanxi Normal University, Shaanxi Xi’an 710119 \\ ${ }^{2}$ School of Public Finance and Tax, Central University of Finance and Economics, Beijing 100081 \\ a email:hxia007@126.com; bemail:machopku@163.com
}

Keywords: Crude Oil Futures; Crude Oil Spot; Pricing Efficiency; Price Discovery

\begin{abstract}
Based on the daily data of international crude oil futures prices and China's crude oil spot prices between January 1, 2006 and May 20, 2016, this paper systematically analyzes the pricing efficiency and lead-lag relationship between international crude oil futures prices and China's crude oil spot prices employing cointegration theory, error correlation, permanent instantaneous model as well as quantified regression method. The empirical results show that : (1)The cointegration coefficient of international crude oil futures prices and China's crude oil spot prices is $(1,-1.0928)$, which illustrates higher pricing efficiency of international crude oil futures prices to China's crude oil spot prices; (2) international crude oil futures prices and China's crude oil spot prices exhibit mutual lead-lag relations, although the impact of futures prices to spot prices is more obvious; (3) the rate of new information to be integrated into the market is up to $84.33 \%$, with the future market playing a dominant role in the transmission of information, and serving as the major driving force in the process of price discovery; (4) the interaction between crude oil future prices and China's crude oil spot prices shows on asymmetric features which illustrates a leverage effect on market volatility.
\end{abstract}

\section{Introduction}

As an important energy and basic product, crude oil is known as "industrial blood”. With the sharp increase in energy demand among countries around the world, the relationship between crude oil and economic development of various countries has become closer. Every fluctuation in oil prices has exerted more or less influence on the economies of all countries in the world, and has become the focus of universal attention in all countries of the world. According to the World Bank's 2014 World Economic Development Report, for every \$10 increase in oil prices and one year, the growth rate of the world economy will be reduced by an average of 0.5 percentage points, and the economic growth rate of developing countries will be reduced by 0.75 percentage points. China is the world's largest net importer of crude oil. The dependence of crude oil on foreign countries is as high as $60 \%$. The impact of international crude oil price fluctuations on China's economy has become increasingly significant. It has become an important factor affecting China's stable economic development and national security. Social development and national security are invaluable. At the same time, due to the super-economic nature of crude oil, countries around the world are vying to control the price of crude oil. Therefore, crude oil has always been an important factor affecting the political orientation of big countries.

Stabilizing crude oil prices has always been a core issue in the macro management of countries around the world. Since China's crude oil price management system reform in 1978, crude oil pricing has been linked to international crude oil prices, and has gradually evolved into a basket of crude oil prices in subsequent reforms. China's crude oil pricing mechanism means international crude oil futures prices. The changes will directly or indirectly affect China's crude oil industry and economic development, and objectively require us to use the international crude oil market to manage crude oil price risks. As we all know, the global crude oil trade generally adopts the method of basis pricing, which is generally based on the price of a crude oil futures contract of Brent or West Texas Intermediate (WTI), plus or minus the agreement between the two parties. The basis is 
used to determine the spot price. This basis pricing method means that the country or region of the international trade of bulk commodities is based on the relevant varieties of the futures exchanges of the country or region, and the country or region has the right to speak. Currently, futures prices have become the most important benchmark price for the international crude oil spot market. WTI crude oil futures and Brent crude oil futures are the two most important pricing benchmarks for the global crude oil market. As the world's most dependent Asian crude oil market, there is currently no benchmark crude oil, so it cannot fully reflect the real market supply and demand relationship in Northeast Asia, which leads to the generally high crude oil prices in the Middle East. Bear the import premium.

On the one hand, China imports a large amount of crude oil, on the other hand, it lacks a crude oil futures market and a strategic reserve of crude oil. Social resources are not effectively utilized, resulting in the pricing power falling. The increasingly significant financial nature of the crude oil market directly led to the ups and downs of oil prices, which brought great threats to the steady growth of the world economy, especially emerging economies such as China, which is at a critical stage of industrialization and urbanization. However, since China has not established its own crude oil futures market, the objective fact of China's lack of crude oil pricing discourse rights in the international crude oil market needs to be broken. The significance of China's active preparation of crude oil futures exchanges is here.

\section{The data description and basic characteristics test}

Stationarity test. Table 1 shows the ADF test and PP stationarity test results of the logarithmic sequence and the first-order difference sequence of international crude oil futures and China's crude oil spot price. Considering that the crude oil market is vulnerable to many external factors in the development process, in order to make the test results more stable, we also consider the unit root DF-GLS test including outliers and structural mutations (Liu et al., 2013). The results of robustness test show that the horizontal sequence of international crude oil futures price and China's crude oil spot price are non-stationary time series; but the difference form, that is, the price-yield sequence of both, rejects the unit at the $1 \%$ significance level. The root hypothesis is a smooth time series, so a cointegration model can be constructed.

Table 1 International crude oil futures and China's crude oil spot price and price return rate sequence stability test

\begin{tabular}{|c|c|c|c|c|}
\hline & $\begin{array}{l}\text { ADF statistic } \\
\text { statistic DF }\end{array}$ & $\begin{array}{ll}\text { GLS } & \text { test } \\
\text { Conclusion } & \end{array}$ & $\begin{array}{l}\text { ADF statistic PP } \\
\text { statistic DF }\end{array}$ & $\begin{array}{l}\text { GLS test } \\
\text { Conclusion }\end{array}$ \\
\hline$f$ & -2.1922 & -2.1934 & -2.1586 & Non-stable \\
\hline$C$ & -1.8186 & -1.9964 & -1.8460 & Non-stable \\
\hline$\Delta f$ & $-50.9097^{* * * *}$ & $-50.9980^{* * *}$ & $-5.3663^{* * * *}$ & smooth \\
\hline$\Delta c$ & $-51.2501^{* * *}$ & $-51.0718^{* * *}$ & $-4.1635^{* * *}$ & smooth \\
\hline
\end{tabular}

Note: $* * *, * *$, and $*$ indicate significant levels at $1 \%, 5 \%$, and $10 \%$, respectively.

2. Autocorrelation test. The results of the stationarity test show that the international crude oil futures price return series and China's crude oil spot and several yield series are stable time series, so we test the autocorrelation of the two. Through the autocorrelation and partial autocorrelation tests of international crude oil futures and China's crude oil spot price yield series, it can be seen that there is a significant correlation between the international crude oil price return series and China's crude oil spot price yield series and its one-stage lag value. Therefore, in order to eliminate the sequence autocorrelation, the mean equation of international crude oil futures and China's crude oil spot price yield is set as follows:

$$
\begin{gathered}
r_{f, t}=\alpha+\alpha r_{f, t-1}+\varepsilon_{f, t} \\
r_{c, t}=\alpha+r_{c, t-1}+\varepsilon_{c, t}
\end{gathered}
$$


The newly established (16) and (17) types are no longer subject to autocorrelation.

Granger causality test. The Granger causality test is mainly used to analyze the causal relationship between economic time series variables. Its essence lies in whether the lag variable of one variable can be introduced into the equation of other variables, and whether the lag variable is added makes the degree of interpretation of the equation increase. If a variable is significantly affected by the lagging variables of other variables, it can be determined that there is a Granger causal relationship between the variables (Gao, 2009). Due to the requirement of the smoothness of the data sequence in the Granger causality test, according to the results of the stationarity test, the Granger causality test will use the first-order difference form of the international crude oil futures price and the logarithm of the spot price of crude oil in China. Table 2 gives the Granger causality test results of the international crude oil futures market and China's crude oil spot market price fluctuations under the optimal lag period under the criteria. The results show that under the 10\% significance level, the international crude oil futures price and China's crude oil spot price are each Granger causal.

Table 2 Granger causality test between international crude oil futures price and China's crude oil spot price

\begin{tabular}{llllll}
\hline Non-zero hypothesis & $\begin{array}{l}\text { Number } \\
\text { observations }\end{array}$ & of & F statistic & Probability & conclusion \\
\hline$\Delta f$ is not $\Delta c$ & Granger reason & 2213 & 1560.2700 & 0.0000 & Refuse \\
$\Delta c$ is not $\Delta f$ & Granger reason & 2213 & 2.5466 & 0.0786 & Refuse \\
\hline
\end{tabular}

\section{Empirical test}

From the results of the stationarity test in Table 1, the results of the three unit root tests show that the horizontal sequence can not reject the assumption of the existence of the unit root at the $1 \%$ significance level; but the first-order difference form, that is, the price gain of the two The rate sequence did not have a unit root at a significance level of $1 \%$. Therefore, it can be considered that the international crude oil price return rate series and China's crude oil spot price yield series satisfy I(1), and can co-integrate the international crude oil price and China's crude oil spot price.

Before performing the Johansen cointegration test and the vector error correction model test, we should first determine the lag order of the model. This lag order is determined by several criteria: First, it must satisfy the mathematical stability, that is, to meet the stability. Sexual requirements, which requires that the reciprocal of all unit root film should fall within the unit circle; second, must meet the LR test criteria; third, the error test must be set by the model, such as normality, autocorrelation, ARCH effect And heteroscedastic effects. According to the four information criteria of AIC, SBIC, HQIC and FPE, we obtain the optimal lag order of the Johansen cointegration test and VEC model is 4 . Table 3 shows the results of the cointegration test between the international crude oil futures price and the spot price of crude oil in China. The assumption is that there is no cointegration relationship between the variables. The maximum eigenvalue test and the trace statistic test show that there is at least one cointegration equation between the two variables during the sample period, that is, there is a long-term cointegration relationship between the two variables, so we can establish a VEC model.

Table 3 Co-integration test between international crude oil futures price and China's crude oil spot price

\begin{tabular}{|c|c|c|c|c|c|}
\hline $\begin{array}{l}\text { Cointegration equation } \\
\text { number hypothesis }\end{array}$ & Eigenvalues & $\begin{array}{l}\text { Trace } \\
\text { statistics }\end{array}$ & $5 \%$ threshold & $\begin{array}{l}\text { Maximum } \\
\text { statistic }\end{array}$ & $5 \%$ threshold \\
\hline $\begin{array}{l}\text { There is no cointegration } \\
\text { equation }\end{array}$ & 0.0069 & 18.0824 & 15.4947 & 15.3200 & 14.2646 \\
\hline $\begin{array}{l}\text { There is a co-integration } \\
\text { equation }\end{array}$ & 0.0013 . & 2.7624 & 3.8415 & 2.7624 & 3.8415 \\
\hline
\end{tabular}

Note: The trace statistic shows that there is 1 cointegration equation (at a 5\% significance level); 
* indicates that the test results reject the null hypothesis (at a 5\% significance level);

** refers to the value of Machinnon-Haug-Michelis (1999) p;

Trend hypothesis: Cointegration test and VEC model contain linear determinable trend items and intercept terms

\section{Conclusions and policy recommendations}

This paper selects the daily data of international crude oil futures price (US\$/barrel) from January 4, 2006 to May 20, 2016 and China's crude oil spot price (USD/barrel), using error correction model, permanent instantaneous model and points. The digit regression method systematically analyzes the pricing efficiency of international crude oil futures prices and China's crude oil spot prices and the lagging-guiding relationship between the two. The empirical analysis found that: (1) The international crude oil futures market has higher pricing efficiency and price discovery function for China's crude oil spot market; (2) There is a two-way guiding relationship between the international crude oil futures market and China's crude oil spot market, and the international crude oil futures market is for China. The guidance of the crude oil spot market is greater than the guidance of China's crude oil spot market on the international crude oil futures market; (3) the ratio of new information into the international crude oil futures market is $84.33 \%$, indicating that the international crude oil futures market is in a dominant position in information transmission. It is the main driving force in the price discovery process; (4) There is a difference between the international crude oil futures price under different quantile conditions and the spot price of crude oil in China, showing the leverage effect of market fluctuations.

In summary, the international crude oil futures market has higher pricing efficiency for China's spot. However, in the future development process, we still need to do the following work: (1) Establish China's own crude oil futures market, give play to the pricing effect of the crude oil futures market on the spot market, price guidance, hedging function, use of crude oil Futures contracts stabilize excessive fluctuations in the spot price of crude oil. (2) Do a good job in investor risk promotion and risk popularization. The high leverage and high risk and high profitability of the crude oil futures market may cause excessive speculation in the crude oil futures market. Therefore, while establishing the crude oil futures market, it is necessary to deepen the basic knowledge of crude oil futures, strengthen the risks of the futures market, strengthen risk education, and guide investors to make reasonable and moderate investments. (3) While creating the crude oil futures market and popularizing financial knowledge, it is necessary to continuously innovate the types of crude oil futures products to enhance the trading vigor and competitiveness of the futures market, and to exert the price stability and risk transfer effect of the crude oil futures market on the spot market.

\section{Acknowledgements}

Fund Project: This paper is funded by a sub-project of the National Key Research and Development Program of China "Economic and Social Benefit Evaluation and Long-term Mechanism Construction of Northern Wheat Weight Loss and Drug Reduction" (2018YFD020040810); National Natural Science Foundation of China Youth Fund Project "Transmission Mechanism and Forecasting Effect of Financial Factors on Corn Price Fluctuation :Based on the perspective of food finance (Project No. 71603153); Key Research and Development Program of Shaanxi Province "Study on Long-term Multidimensional Poverty, Poverty Factors and Poverty Reduction Policies for Children in Shaanxi" (2018KW-065); Fundamental Scientific Research Funds of Central Universities in Shaanxi Normal University The special fund project "Evaluation of Comprehensive Benefits of Fertilizer and Pesticide Reduction Technology in Dryland Wheat in the Loess Plateau” (GK201803092). 


\section{References}

[1] Alquist R and Kilian L. What do we learn from the price of crude oil futures? Journal of Applied Econometrics, 2010, 25: 539-573.

[2] Antoniou A, Holmes P and Priestley R. The effects of stock index futures trading on stock index volatility: an analysis of the asymmetric response of volatility to news. Journal of Futures Markets1998, 18: 151-166.

[3] Baumeister C and Kilian L. Real-time forecasts of the real price of oil. Journal of Business and Economic Statistics, 2012, 30: 326-336.

[4] Baumeister C and Peersman G. The Role of Time-varying Price Elasticities in Accounting for Volatility Changes in the Crude Oil Market. Journal of Applied Econometrics, 2013, 28: 1087-1109.

[5] Cornell B and French K. Taxes and Pricing of Stock Index Futures. Journal of Finance, 1983, 13(38):675-694.

[6] Dvir E and Rogoff K. Three epochs of oil. Mimeo, Department of Economics, Harvard University, 2010.

[7] Foster A J. Price discovery in oil markets: a time varying analysis of the 1990-91 Gulf conflict. Energy Economics, 1996,18: 231-246.

[8] Garbade K D and Silber W L. Price movement and price discovery in futures and cash markets. Review of Economics and Statistics, 1983,65: 289-297.

[9] Gonzalo J and Granger C W J. Estimation of Common Long-memory Components in Cointegrated Systems. Journal of Business \& Economic Statistics, 1995, 13: 27-35.

[10]Hamilton J D. Causes and consequences of the oil shock of 2007-08. Brookings Papers on Economic Activity, 2009a: 215-261.

[11]Hamilton J D. Understanding crude oil prices. Energy Journal, 2009b, 30(2): 179-206.

[12] Hamao Y, Masulis R W and Ng V. Correlations in Price Changes and Volatility across International Stock Markets, The Review of Financial Studies, 1990, 3 (2): 281-307.

[13]Hasbrouck J. One Security, Many Markets: Determining the Contributions to Price Discovery. Journal of Finance, 1995, 50: 1175-1199.

[14]Huang Y C. Trading activity in stock index futures markets: evidence of emerging markets. Journal of Futures Markets, 2002, 22 (10): 983-1003.

[15]Huang B N, Yang C W and Hwang M J . The dynamics of a nonlinear relationship between crude oil spot and futures prices: A multivariate threshold regression approach. Energy Economics, 2009, 31: 91-98.

[16]Illueca $\mathrm{M}$ and Lafuente $\mathrm{J}$ A. The effect of spot and futures trading on stock index market volatility: a nonparametric approach. The Journal of Futures Markets, 2003, 23 (9): 841-858.

[17]Kaufmann R K and Ullman B. Oil prices, speculation, and fundamentals: Interpreting causal relations among spot and futures prices. Energy Economics, 2009, 31: 550-558.

[18]Kilian L. Not all oil price shocks are alike: disentangling demand and supply shocks in the crude oil market. American Economic Review, 2009, 99: 1053-1069.

[19]Kilian L and Murphy D P. The Role of Investments and Speculative Trading in the Global Market for Crude Oil. Journal of Applied Econometrics, 2014, 29: 454-478.

[20]Koenker R and Bassett G. Regression Quantiles. Econometrica, 1978, 46: 33-50.

Koontz S, Garcia R and Hudson M A. Dominant-satellite relationship between live cattle cash and 
futures markets. The Journal of Futures Markets, 1990, 10: 123-136.

[21]Maslyuk S and Smyth R. Cointegration between oil spot and future prices of the same and different grades in the presence of structural change. Energy Policy, 2009, 37: 1687-1693.

[22]Moosa I A. Price Discovery and Risk Transfer in the Crude Oil Futures Market: Some Structural Time Series Evidence. Economic Notes, 2002, (31)1: 155-165.

[23] Oellermann C M, Brorsen B W and Farris P L. Price discovery for feeder cattle. The Journal of Futures Markets, 1989, 9: 113-121.

[24]Quan J. Two Step Testing Procedure for Price Discovery Role of Futures Prices. Journal of Futures Markets, 1992, 12: 139-49.

[25]Schwarz T V and Szakmary A C. Price Discovery in Petroleum Markets: Arbitrage, Cointegration, and the Time Interval of Analysis. Journal of Futures Markets, 1994, 14:147-67.

[26] Schroeder T C and Goodwin B K. Price discovery and cointegration for live hogs. The Journal of Futures Markets, 1991, 11: 685-696.

[27]Wu H and Li S. Volatility Spillovers among China's Crude Oil, Corn and Fuel Ethanol Markets. Energy Policy, 2013, 62: 878-886. 